\title{
Chinese Higher Education Development and Countermeasure Research
}

\author{
Yan Liü, a \\ ${ }^{1}$ Northeast dianli uniersity school of Marxism china; northeast normal university china \\ a965204184@qq.com
}

Keywords: higher education, development, countermeasure, research

\begin{abstract}
. since 1999 began to enter the rapid enrollment expansion of colleges and universities, Chinese higher education has experienced vigorous development, our country's higher education five years earlier than scheduled time is in 2005 entered the stage of popular education stage, the elite education, along with the arrival of the stage of popularization of higher education, higher education is faced with many problems, at present our country's higher education has been from quantity growth to quality improvement stage, improve quality, go the way of connotative development is our country's higher education reform and development of the core task.
\end{abstract}

\section{The higher education from elite education to popular education background}

The influence of economic factors. Since 1997, the economic crisis of southeast Asia to make the entire Asian economy overshadowed, almost all of the country's foreign trade are badly affected, exports to the survival of China's economic growth were hit by an unprecedented countries began to develop policies to expand domestic demand, adjust the national economy from dependence on foreign economic model for the internal and external and repairing. In February 1999, the Asian development bank economist Dr Shang Min with Asian school of management professor xiaolei zuo planning out the weak economic stimulus plan. I.e., increasing the speed of $25 \sim 30 \%$ per year, 3 years to make our university (including adult college) enrollment volume doubled.[1] Chinese people, especially the farmers most will not advance consumption, like save money, however, they are willing to invest money in the next generation, especially on their children's education.

The adjustment of education policy. The party central committee and the state council held after the reform and opening to the outside of the third national education work conference on the eve of the premier of the state council office meeting made greatly expand the scale of enrollment of institutions of higher learning. During the meeting, zhu announced the decision. When the decision is mainly caused by: (1) the sustained and rapid development of China's economic and social needs more high-quality talent; (2) the people common desire their children to receive higher education, the government has a responsibility to try to meet their desire; (3) the enrollment expansion of colleges and universities can also delay the high school graduates employment, increase the education consumption, stimulating domestic demand, driving the development of relative industries; (4) the past enrollment ratio is too low for a long time, difficult to get into college, affected the full implementation of quality education in basic education. In the third national education work conference announced that greatly expand the scale of enrollment in colleges and universities, and make the meeting greatly expand the scale of enrollment in colleges and universities.[2]

On June 13, 1999, the party central committee and the state council issued "the central committee of the communist party of China, the state council on deepening education reform and comprehensively promote quality education decision" points out, through various forms to actively developing higher education, in 2010, our country higher education enrollment rate of school-age population from the current $9 \%$ to $9 \%$. Therefore, colleges and universities throughout the country entered the history of higher education since the founding of the one of the biggest expansion, higher education of our country has entered an unprecedented development in the new period, historic changes have taken place in higher education scale, in as little as five or six years, the university recruitment of students scale for nearly three times, the results showed that in 2005 mainland China school-age youth school enrollments in colleges and universities ranking second in 
the world, second only to America. Originally scheduled for implementation of the university in 2010 before the gross enrollment ratio of $15 \%$ to 2005, earlier than scheduled for 5 years to complete, Martin, put the development of higher education is divided into three stages, namely elite stage, stage of popularization and popularization stage. He thinks this is a sign of three stages respectively enrollment accounted for less than $15 \%$ of the school-age population, $15 \%-50 \%$ and more than $50 \%$. It follows that our country's higher education has historically entered the internationally recognized the popularization of higher education stage. Higher education in China in just 12 years of time, the gross enrollment ratio rose from 3.4\% in 1990 to 15\% in 2002. With in this regard, the United States for 30 years, use for 14 years, South Korea, Japan for 23 years, Brazil spent 26 years, our country's higher education entered the popular stage faster than some developed countries.

\section{The popularization of higher education into the phase of the present situation and the problems we are facing}

The current situation of enrollment expansion of colleges and universities. Since 1999 to expand the scale of enrollment in colleges and universities, a major increase in the number of college students. From the 1998 national ordinary college recruit students 1.08 million people, to the 2002 national college recruit students 2.75 million people, is as high as $154.6 \%$, according to the China statistical yearbook 2011, by the end of 2010, the number of 22.317929 million students in common colleges and universities. According to the law of the People's Republic of China in 2011, the national economic and social development statistical bulletin: student 23.085 million people, ordinary this specialized subject annual enrollment of 6.81 million, 2011, the gross enrollment ratio of $26.9 \%$, to further improve China's popularization of higher education level, nearly 30 million people in total scale ranks first in the world, and the gross enrollment ratio increased from $15 \%$ in 2005 to $26.9 \%$ in 2011. 2010, our country has a higher degree of education culture of the population of 119 million people, in every 100000 people with a higher degree of education culture from 2000 in 3611 to 2010 in 8930, high-level professional and technical personnel to strengthen significantly. At present, the Chinese higher education has become a veritable big country, is moving towards higher education power.

With the popularization of higher education entered the stage of accelerated, most of the working-age population has equal access to higher education. Want to accomplish several generations university dream realized at this stage. To achieve the original intention of this policy, increasing domestic demand, promoting the economic growth, to solve the problem of employment, to China's overall national quality at the same time improve played a role, for the modernization construction continuously conveying the high-level personnel, provides a high level of intellectual support and social services. To our country in the 21st century knowledge-based, informationization, the globalization competition, has the inestimable role.

After the enrollment expansion of higher education development faces many problems. Due to rapidly expand the scale of enrollment, many colleges and universities in the way of running a school on the existence of the local, to strengthen the teaching of hardware and software facilities are not keep up with the pace of enrollment, some colleges and universities, obsolete teaching facilities and lack of teaching quality monitoring does not reach the designated position, unreasonable examination system, teaching management means obsolete backwardness and rigid teaching system, the old teaching materials, curriculum is not reasonable, the teaching plan and content cannot be very good to adapt to the social demand for knowledge update, teacher vacancy, teacher's teaching burden, some colleges and universities a teacher a semester is responsible for two or three courses teaching, inadequate experience, the serious influence the improvement of teaching quality, more have no time to attend in a advanced studies and further education, teachers' lack of knowledge update, due to the lack of teachers, especially the serious shortage of common class and foreign language teachers, some universities organization YiErBai students more concentrated in the center of the hall or activity classes, any teaching effect, these are seriously affecting the quality and level of higher education of talent training. In addition, colleges and universities in order to raising 
funds for expansion, debt has become a common phenomenon, debt management in colleges and universities make some universities in enrollment expansion and expanding circle, affecting the healthy development of China's higher education cause.

The disadvantages of enrollment expansion of colleges and universities also highlighted on talent training, successive years of enrollment expansion, the pressure of employment, education value, the human cost down. The good and evil people mixed up college students, the good and bad are intermingled, overall quality to drop, emptiness, sexual liberation of religion and other moral problems emerge in endlessly. Vulgar way of cultivating the cultivation of college students, such as the products on assembly line, didn't pass strict test in the junior year just one end is to the society, the quality is not completely accord with the demand of the society, unit of choose and employ persons, some graduates cannot adapt to the work as soon as possible, incomplete knowledge reserves, basic vocational training is insufficient, hands-on practice ability is weak, lack of team spirit and dedication will still need to temper, suffering mentality is not mature, and critical nature of work, can quickly into social work, the number of college graduates increased year by year, directly caused the college students' employment difficulty, and graduate entrance examination pressure, caused a serious shortage of skilled workers in young adults. College graduates unemployment number increasing trend year by year, caused the education costs and serious waste of social resources, brought down the investment of education, millions of families increased social instability.

Due to education and teaching methods and means a lack of innovation in the knowledge structure of students in China for flaws in performance, explicit knowledge and tacit knowledge; Theoretical knowledge and practical knowledge. Explicit knowledge advantage make us in basic education stage with the developed countries seem difficult points up and down, but the disadvantage of the recessive knowledge education in our country's higher education stage in a state of obvious lag behind. Is common in Chinese colleges and universities a clear case for the learning of English, foreign language education research centre in 2004 to more than 4000 non-english major college students conducted a survey, $19 \%$ of the students "almost all the time on English study, 56\% of the students" most of the time spent on English learning. In order to make students learn English, Chinese college English level as a standard of assessment of students can graduate, for non-english major students request through the national English four levels, and unit of choose and employ persons also put the English level as a condition of measure whether the student has the qualifications of the interview, but to practice English and not everyone can use, no other country in the world like Chinese university students spend so much of the cost study exam-oriented English without using value, and the amount of useless in learning English no doubt increased the Chinese youth time costs in terms of success. The British council official, according to data released by the Chinese ielts(International English Language Testing System) candidates in the writing and speaking single exam score is the lowest in recent years. McKinsey survey in 2006, according to data from China (mainland) less than $10 \%$ of the college students' English communication ability.

\section{The countermeasures of development of higher education reform in our country}

The connotative development, the development of higher education reform direction. On May 10, 2006 the state council executive meeting, heard the work report by the higher education, the meeting fully affirmed, in recent years, our country's higher education development and reform has achieved obvious achievements, provided the chances of receiving higher education of the people, improve the overall quality of population in our country, for the modernization construction has trained a large number of high-quality talent, made an important contribution for the national economic and social development. But, our country's higher education in the process of the popularization education transformation, have appeared in the scale of colleges and universities blindly expand, the problem such as the decrease of the quality of the talents cultivation, the connotation of higher education development is on the agenda. It is in this background, the cause of higher education in the report to the party 18 proposed many new thoughts, new requirements, our understanding of higher education to a new level, and for the first time put forward "to promote 
higher education connotation development" ${ }^{[4]}$ a new idea, establishes the new historical period of higher education in the direction of scientific development. Higher education connotation development is based on the concept of scientific development as guidance, insist on higher education better, faster, more comprehensive and coordinated development, pay more attention to the quality and efficiency of ascension.

The development of higher education connotation, it is necessary to vigorously promote personnel training level. The basic task of higher education is talent cultivation. At the first standard is to measure the quality of higher education talent training level, the core is to solve what person, how to cultivate people's major problems. First of all, we must strengthen cultivating innovative talents, set up the innovation education idea. To create a social climate favorable for the cultivation of innovative talents, to cultivate top-notch innovative talents needs according to their aptitude, has good example, need individualized teaching, differentiation, need according to the students' interest, special features and basic, stimulate students' creativity and development potential. Can be adhering to the research-oriented teaching, academic starting point, the new idea of inquiry learning, let the students scientific research front, direct contact to participate in the competition of science and technology or with professor do research projects, develop students' innovative thinking in the project research, cultivate students' autonomous learning and innovation ability in scientific research, cultivation of innovative talents, should actively advocates the teaching model of collaborative innovation ${ }^{[5]}$, collaborative innovation is not only an important way to improve national innovation ability, and cultivate innovative talents in colleges and universities, improve the inevitable requirement of scientific research ability. Colleges and universities to the concept of "cooperative" to promote the reform of scientific research, break the closed dispersion pattern, giving full play to the advantages of multidisciplinary multi-purpose, promote innovation elements organic integration and sharing in an all-round way. Colleges and universities should renewal education idea, and innovate talent training new way of thinking, to promote the innovative talent training mechanism of change.

The development of higher education connotation, to strengthen the construction of teaching staff and training. To promote the development of higher education connotation, key lies in the teachers. Under the state council on strengthening the construction of teachers' opinions (guo fa [2012] no. 41) pointed out that "teacher is the foundation of the education career, is to improve the quality of education, do a good job in the key of the people's satisfactory education. High school teachers team construction to focusing on young and middle-aged teachers and innovation team, optimize the middle-aged and young teachers' growth development and stand out from the system environment, to foster interdisciplinary, interdisciplinary research and teaching with the combination of innovation team". To strengthen the construction of teachers team, the first to deepening the reform of the system of selecting and appointing teachers in colleges and universities, the majority of college teachers are "inbreeding" phenomenon, hindered the academic schools of thought contend, is not conducive to thought of collision and talent exchange, to a certain extent, hampered the innovative ideas. Deepen the system of hiring teachers, to broaden horizons and improve the system of selection, fully implementing the open recruitment, promote communication between different colleges and schools. Encourage universities to hire practice experienced experts mtcsol, encourage teachers have abroad and learning, research and work experience, optimize the structure of teachers. Secondly to improve the academic level of teachers, students' learning most was conducted under the guidance of teachers, teachers' influence on college students' learning content and direction, so the high level of teachers to cultivate high level talented person, in addition to outside the introduction of a high level of teachers, teachers in colleges and universities to encourage the university for further study, create favorable environment for teachers' quality and ability of ascension, in the achievements of academic and academic teachers give corresponding material reward, at the same time influential professor on campus and off to become a kind of teaching norm undergraduate class. Again, improve the quality of education, cultivate innovative talents, to set up the mechanism of the cultivation of the innovative teachers, the so-called innovative teachers, is a strong thirst for knowledge and tact to the teachers. They have a love of 
science, the pursuit of truth, exploration, curious about the unknown of things; They have in view of the education object, education content and education situation, the characteristics of a target to put forward new ideas; They thought liberation and innovation. At present, China's colleges and universities also need to establish the cultivating innovative teachers' training system and the specific standard of evaluation system of innovative teachers. To improve the quality of higher education, go the way of connotative development, to cultivate the innovative talents, and the cultivation of innovative talents depends on innovative teachers, cultivating innovative teachers is the prerequisite of enhance the level of talent training. Finally, to strengthen the construction of teacher's ethics is the key to improve the level of talent training, "teacher, so the preaching, knowledge, to reassure also". "Preach", namely, a professor at the life of truth, is the primary task of teachers, as people's teacher, first of all to do a teacher by worthy example, establishing the image of good virtue, teachers good ideological morality will be the greatest embodies the personality, teacher's quality directly affects the quality of the students and school ethos, teachers in word and deed, education guiding role to the student, that affect a person's a student, and influence a person's life. Teachers only consciously strengthen moral accomplishment, governs incorruptibly, to become a student mentor, become a mentor and lead the healthy growth of students to become a useful person. As a qualified teacher to do " Great learning makes a teacher; moral integrity makes a model", Confucius said: " The body is, do not order line, the body is not correct, although not from." The teacher should always do students example, use own practical action and personality charm to infect students, so that qualified teachers can produce qualified students.

\section{Acknowledgements}

This article is phased research results of teaching reform projects: teaching reform project of jilin province department of education "ideological and political theory course hidden curriculum resources development and utilization”, no.JX201228, school teaching reform project "ideological and political theory teaching discourse system innovation research” ,no.JX201428 ,and teaching reform project of higher education institute of jilin province "based on the combination of explicit and implicit education in colleges and universities ideological and political education research" no.JGJX2015C36 .

\section{References}

[1] Chonglong Yang, increased enrollment in colleges and universities in our country is put forward and termination, journal of yunnan university for nationalities (philosophy and social science edition) in February, 2007, 24 (2), page 151. In Chinese

[2]The third national education work conference, history of higher education of the People's Republic of China, http://www.nwp.cn/book/720_34412.shtml, In Chinese.

[3] Leap-forward development for the cause of higher education, the history of higher education of the People's Republic of China. In Chinese.

[4] Jintao Hu. Unswervingly along the path of socialism with Chinese characteristics to strive to build a well-off society in an all-round way -- on the eighteenth national congress of the communist party of China report [N]. People's Daily, 2012-11-08 (4), In Chinese.

[5]Ying-jun wang,out of the top creative talent training new road, the guangming daily, jan 04, 2012. In Chinese. 